\title{
PENGARUH WAKTU PERENDAMAN AIR LAUT TERHADAP MUTU PERKERASAN HOT ROLLED SHEET A (HRS A)
}

\author{
Jusmidah $^{1)}$ \\ 1) Dosen Program Studi Teknik Sipil, Universitas Andi Djemma, Palopo \\ 1) jusmidah@gmail.com
}

\begin{abstract}
Abstrak
Musuh utama jalan raya dengan perkerasan aspal adalah air. Untuk mendapatkan taksiran yang lebih teliti dari permasalahan tersebut perlu dilakukan penelitian dengan uji laboratorium tentang, pengaruh genangan / rendaman air (khususnya yang bersifat asin) serta lama waktu rendaman terhadap kualitas campuran beraspal panas. Desain campuran yang dipakai adalah desain untuk jenis campuran HRS A (Hot Rolled Sheet A). Dalam Penelitian ini sampel air laut yang digunakan sebagai air perendaman berasal dari lokasi Teluk Bone yang berhubungan langsung dengan daerah Jalan Lingkar Timur Kota Palopo.Berdasarkan hasil pengujian dan analisa data karakteristik Marshall yang diakibatkan oleh pengaruh rendaman air laut terhadap mutu perkerasan $H R S A$, diperoleh hasil bahwa mutu perkerasan HRS A hanya dapat bertahan selama 4 jam akibat rendaman air laut. Hal ini menunjukkan bahwa rendaman atau genangan air laut dapat merusak keawetan mutu perkerasan. Setelah melakukan uji perendaman menggunakan air laut diperoleh Indeks Stabilitas Sisa (IRS) pada rentang waktu perendaman 24 jam yaitu sebesar 32,92\%. Hal ini diakibatkan oleh pengaruh air laut yang merusak lapisan aspal yang menyelimuti perkerasan sehingga perekatan antar agregat semakin berkurang. Ini ditunjukkan oleh nilai VIM (Void in Mix) untuk rentang waktu 24 jam mencapai 7,99\%.
\end{abstract}

Kata Kunci: Waktu perendaman, mutu, HRS-A

\section{PENDAHULUAN}

Keawetan suatu campuran aspal berhubungan dengan kemampuannya untuk menahan kerusakan akibat pengaruh air dan suhu. Kehilangan keawetan adalah merupakan faktor utama dalam kegagalan suatu perkerasan. Ketika perencanaan suatu campuran, keawetan umumnya ditaksir dengan meninjau kehilangan atas kekuatan melalui perendaman dalam waktu yang relatif singkat di dalam air pada suhu tinggi. Pengujian seperti itu tidak dapat memberikan suatu taksiran yang teliti dari pengaruh jangka panjang akibat masuknya air. Di beberapa wilayah Indonesia, banyak jalan yang berhubungan dengan daerah pantai yang seringkali digenangi oleh air laut pada suhu lingkungan dalam waktu yang lama. Banyak hal yang menyebabkan kerusakan konstruksi jalan, musuh utama jalan dengan perkerasan aspal ada 3 (tiga)adalah yang pertama air, kedua air dan ketiga juga air. Dari hal tersebut dapat dikatakan bahwa (genangan) air menyebabkan kerusakan atau mengurangi keawetan konstruksi jalan dengan perkerasan aspal (Prabowo, 2003).

Untuk mendapatkan taksiran yang lebih teliti dari permasalahan tersebut perlu dilakukan penelitian dengan uji laboratorium tentang, pengaruh genangan / rendaman air (khususnya yang bersifat asin) serta lama waktu rendaman terhadap kualitas campuran beraspal panas. Desain campuran yang dipakai adalah desain untuk jenis campuran HRS - A (Hot Rolled Sheet -A). Dalam penelitian ini sampel air laut yang digunakan sebagai air perendaman berasal dari lokasi Teluk Bone yang berhubungan langsung dengan daerah Jalan Lingkar Timur Kota Palopo

\section{METODOLOGI PENELITIAN}

Daerah yang menjadi lokasi pengambilan agregat adalah pada kelurahan Mancani yang letaknya berkisar $\pm 11 \mathrm{~km}$ dari pusat Kota Palopo, sedangkan lokasi pengambilan 
Air Laut untuk perendaman adalah daerah Jalan Lingkar Timur Kecamatan Wara Timur Kota Palopo yang berbatasan langsung dengan perairan Teluk Bone.

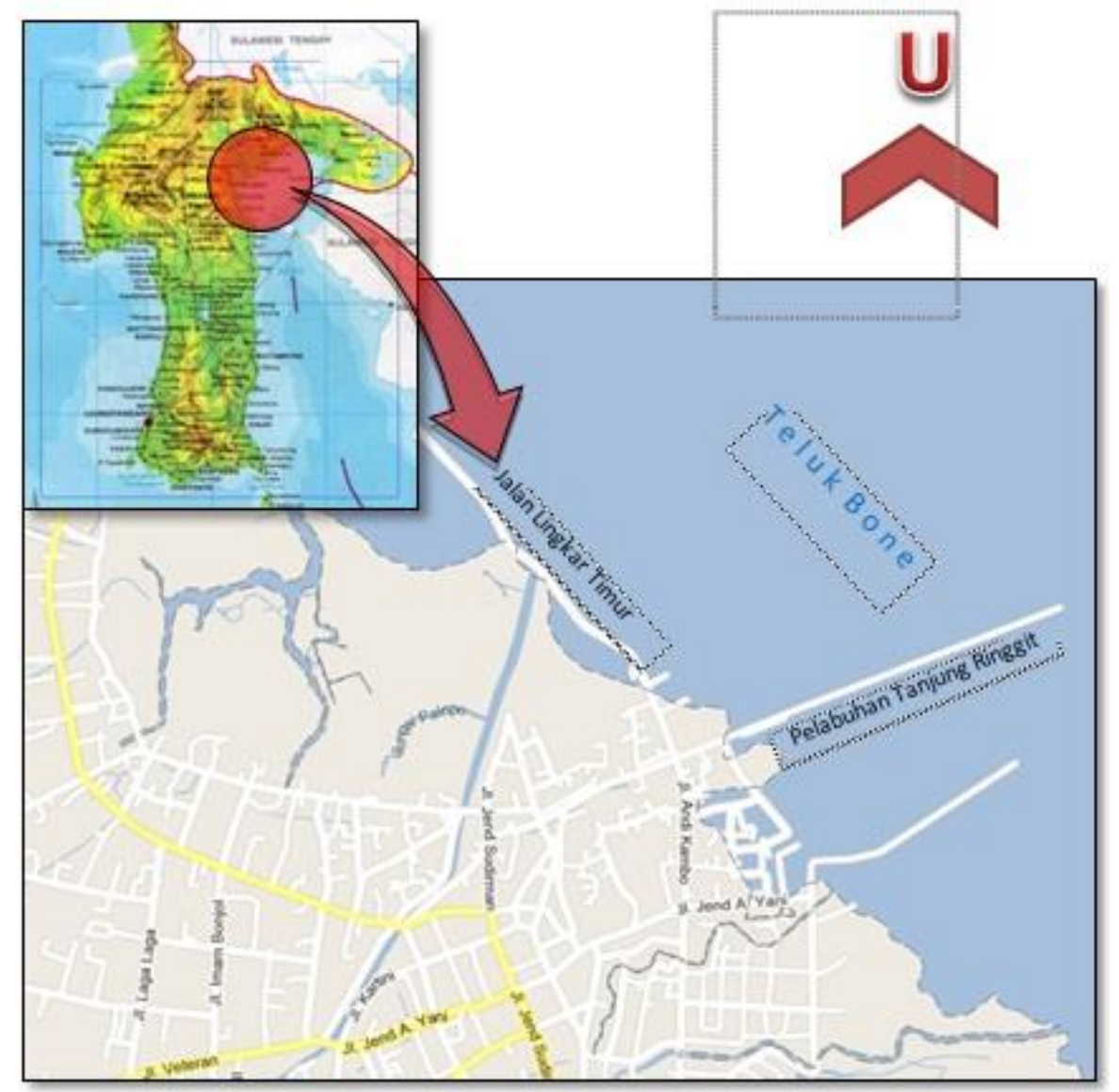

Gambar 1. Peta Lokasi Pengambilan Sampel Air Laut

Secara umum material agregat kasar yang ada berupa batu kali yang telah diproduksi menjadi chipping dan debu batu (filler) dengan ukuran agregat kasar yang bervariasi mulai dari $0,5-1,0 \mathrm{~cm}$ dan $1,0-2,0 \mathrm{~cm}$. Sedangkan pasir yang dipergunakan adalah pasir dari Sungai Makawa yang berada di daerah Lamasi Kabupaten Luwu. Penelitian dilakukan di Laboratorium Bahan Perkerasan Jalan Universitas Andi Djemma. Material yang digunakan berupa aspal, agregat kasar, dan filler

Penelitian yang dilakukan melalui beberapa tahap, mulai dari tahap persiapan, tahap pemeriksaan mutu bahan yang berupa pemeriksaan agregat dan pemeriksaan aspal. Setelah melalui tahap pemeriksaan agregat dan aspal, maka tahap berikutnya adalah tahap perencanaan campuran kemudian dilanjutkan dengan tahap pelaksanaan pengujian dengan Marshall Test.

Perkerasan lentur jalan raya pada hakekatnya merupakan campuran antara agregat kasar, agregat halus, filler dan aspal yang digunakan untuk melayani beban lalu lintas diatasnya. Perkerasan lentur ini diletakkan diatas tanah dasar secara aman yang diperkeras dengan lapisan konstruksi yaitu Lapis Pondasi Bawah (LPB) dan Lapis Pondasi Atas (LPA) yang mempunyai ketebalan, kekuatan dan kekakuan serta kestabilan tertentu seperti yang dipersyaratkan.

Adapun langkah - langkah dalam penelitian ini dapat dilihat pada bagan alir metode penelitian pada gambar 2 berikut ini: 


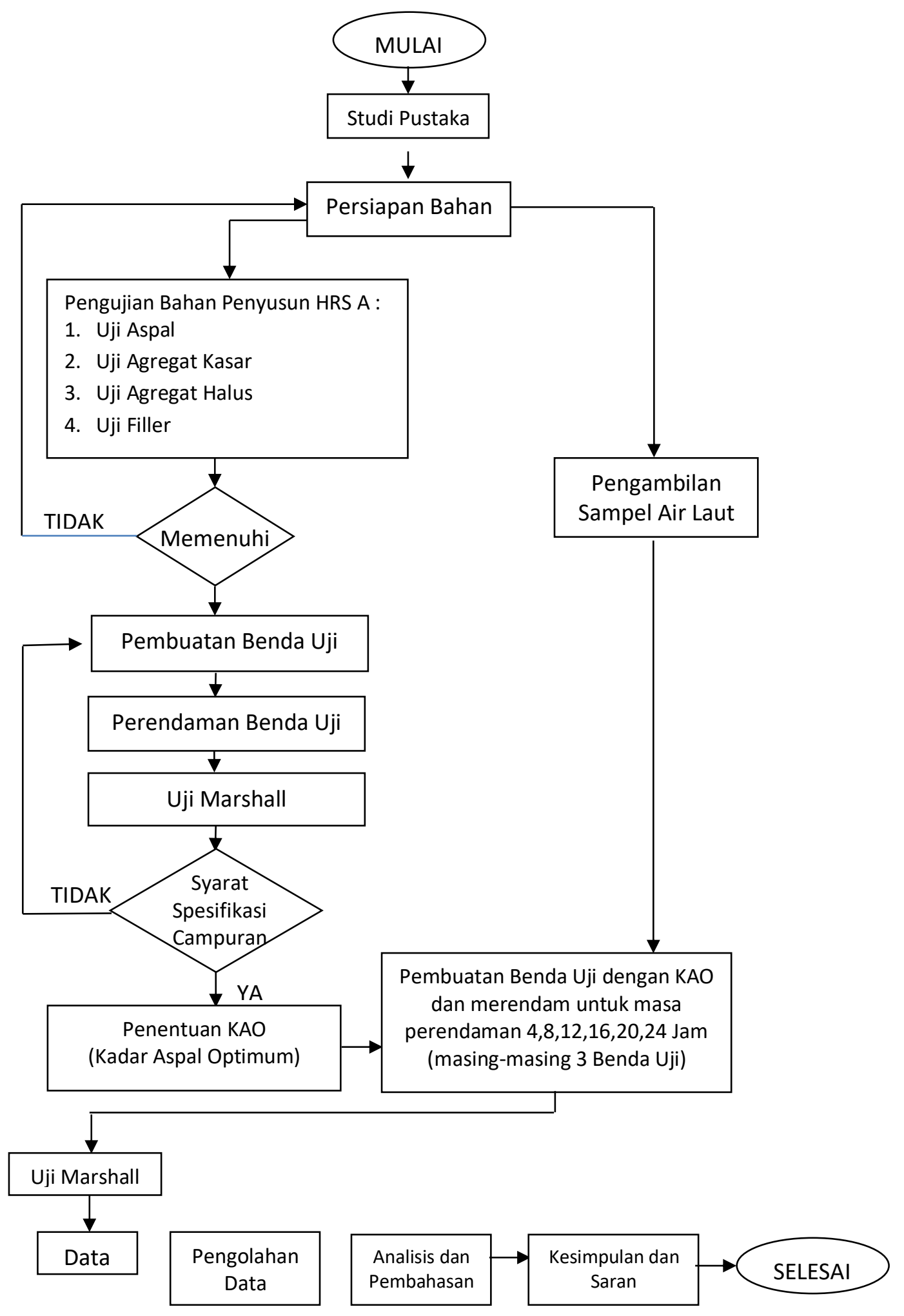

Gambar 2. Bagan Alir Penelitian 


\section{HASIL DAN PEMBAHASAN}

Pengujian material dalam campuran beraspal jenis perkerasan HRS A ini terdiri dari agregat kasar, agregat halus, filler dan aspal. Filler yang digunakan sebagai bahan penelitian adalah abu batu. Kendala dalam pengujian ini adalah kondisi alat timbang yang tidak optimal sehingga perlu dinormalkan setiap saat, sehingga dalam percobaan pemeriksaan perlu perhatian secara khusus.

\section{Hasil Pengujian Material}

\section{Pemeriksaan Kelekatan Agregat terhadap Aspal}

Dari hasil pemeriksaan, diperoleh hasil $96 \%$ spesifikasi Minimum 95

\section{Agregat Halus}

a) Analisa Saringan berikut :

Dari hasil pemeriksaan, diperoleh hasil seperti yang terlihat pada tabel sebagai

Tabel 1. Hasil Pemeriksaan Analisa Saringan Agregat Halus

\begin{tabular}{ccc}
\hline Ukuran Saringan & \% Tertahan & \% Lolos \\
\hline $\mathbf{3 / 4 "}$ & 0 & 100 \\
$\mathbf{1}$ "” & 0 & 100 \\
$\mathbf{3 / 8}$ " & 0 & 100 \\
No.4 & 0 & 100 \\
No.8 & 0,14 & 99,86 \\
No.30 & 22,31 & 77,69 \\
No.100 & 97,18 & 2,82 \\
No.200 & 99,57 & 0,43 \\
PAN & 100 & 0 \\
\hline
\end{tabular}

b) Pemeriksaan Berat Jenis dan Penyerapan Air

Dari hasil pemeriksaan, diperoleh hasil seperti yang terlihat bahwa hasil pengujian berat jenis apparent (semu) agregat halus sebesar 2,61 gr/cm3, menurut spesifikasi Bina Marga berat jenis minimum yang disyaratkan adalah sebesar $\quad 2,5 \mathrm{gr} / \mathrm{cm} 3$. Sedangkan penyerapan air diperoleh hasil sebesar 3,01\%, maksimum penyerapan diperbolehkan sebesar 3\%. Sehingga dapat dikatakan bahwa Agregat Halus (Pasir) yang digunakan memenuhi syarat spesifikasi berat jenis dan penyerapan yang diperbolehkan.

c) Pemeriksaan Sand Equivalent

Pemeriksaan Sand Equivalent dilakukan untuk mengetahui kadar lumpur yang terkandung dalam agregat halus dalam hal ini pasir yang dipergunakan. Bahwa hasil pemeriksaan Nilai Sand Equivalent sebesar 92,38\%, menurut spesifikasi Bina Marga nilai Sand Equivalent yang disyaratkan adalah minimum 50\%. Sehingga dapat dikatakan bahwa Agregat Halus (Pasir) yang digunakan memenuhi syarat spesifikasi Sand Equivalent yang diperbolehkan.

d) Pemeriksaan Soundness Test Agregat Halus

Dari hasil pemeriksaan, diperoleh hasil bahwa persentase kehilangan berat dari agregat halus setelah melalui uji Soundness diperoleh sebesar 10,30\%, menurut spesifikasi Bina Marga persentase kehilangan berat yang disyaratkan adalah maksimum $12 \%$. Sehingga dapat dikatakan bahwa Agregat Halus (Pasir) yang 
digunakan memenuhi syarat spesifikasi persentase kehilangan berat yang diperbolehkan.

\section{Filler}

a) Analisa Saringan

Pemeriksaan analisa saringan untuk filler dimaksudkan untuk pembagian gradasi butir filler pada masing - masing saringan yang dipergunakan untuk campuran perkerasan $H R S$ A. Jenis filler yang dipergunakan dalam penelitian ini adalah abu batu. b) Pemeriksaan Berat Jenis dan Penyerapan Air

Dari hasil pemeriksaan, diperoleh hasil pengujian berat jenis apparent (semu) filler sebesar 2,76 gr/cm3, menurut spesifikasi Bina Marga berat jenis minimum yang disyaratkan adalah sebesar 2,5 gr/cm3. Sedangkan penyerapan air diperoleh hasil sebesar $1,13 \%$, maksimum penyerapan diperbolehkan sebesar 3\%. Sehingga dapat dikatakan bahwa Filler (Abu Batu) yang digunakan memenuhi syarat spesifikasi berat jenis dan penyerapan yang diperbolehkan.

\section{Aspal}

Pemeriksaan Berat Jenis Aspal Keras bertujuan untuk mengetahui berat jenis aspal keras yang dipergunakan dalam campuran perkersan HRS A. hasil pemeriksaan berat jenis aspal keras adalah sebesar 1,013, menurut spesifikasi Bina Marga berat jenis aspal keras yang disyaratkan adalah minimum 1,0 pada temperatur $25^{\circ} \mathrm{C}$. Sehingga dapat dikatakan bahwa Aspal Keras yang digunakan memenuhi syarat spesifikasi berat jenis aspal keras yang diperbolehkan.

\section{Perencanaan Persentase Agregat Campuran}

Dalam memperoleh gradasi agregat campuran yang sesuai dengan spesifikasi gradasi jenis $H R S A$, terlebih dahulu ditetapkan persentase butiran agregat yang lolos nomor saringan tertentu dengan mempertimbangkan batasan gradasi jenis HRS A.

Persentase penggunaan masing - masing agregat dan filler diperoleh dari hasil penggabungan agregat menggunakan metode diagonal yang bersumber dari hasil pengujian analisa saringan agregat kasar, analisa saringan agregat halus dan analisa saringan filler, hasil penggabungan tersebut dapat dilihat pada grafik penggabungan agregat dengan metode diagonal pada gambar 3.

Dari grafik penggabungan agregat pada gambar 3, maka diperoleh persentase masing - masing agregat adalah sebagai berikut (1)Agregat Kasar 33,00\%, (2)Agregat Halus 47,00\%, (3)Filler 20,00\%. Setelah mendapatkan proporsi masing - masing agregat, maka persentase agregat gabungan pada masing - masing saringan yang dipergunakan untuk perkerasan $H R S A$.

Penetapan persentase agregat gabungan seperti pada table 1 di atas telah memenuhi batas gradasi yang disyaratkan untuk lapis perkerasan $H R S A$, seperti terlihat pada grafik kurva gradasi agregat berikut ini : 


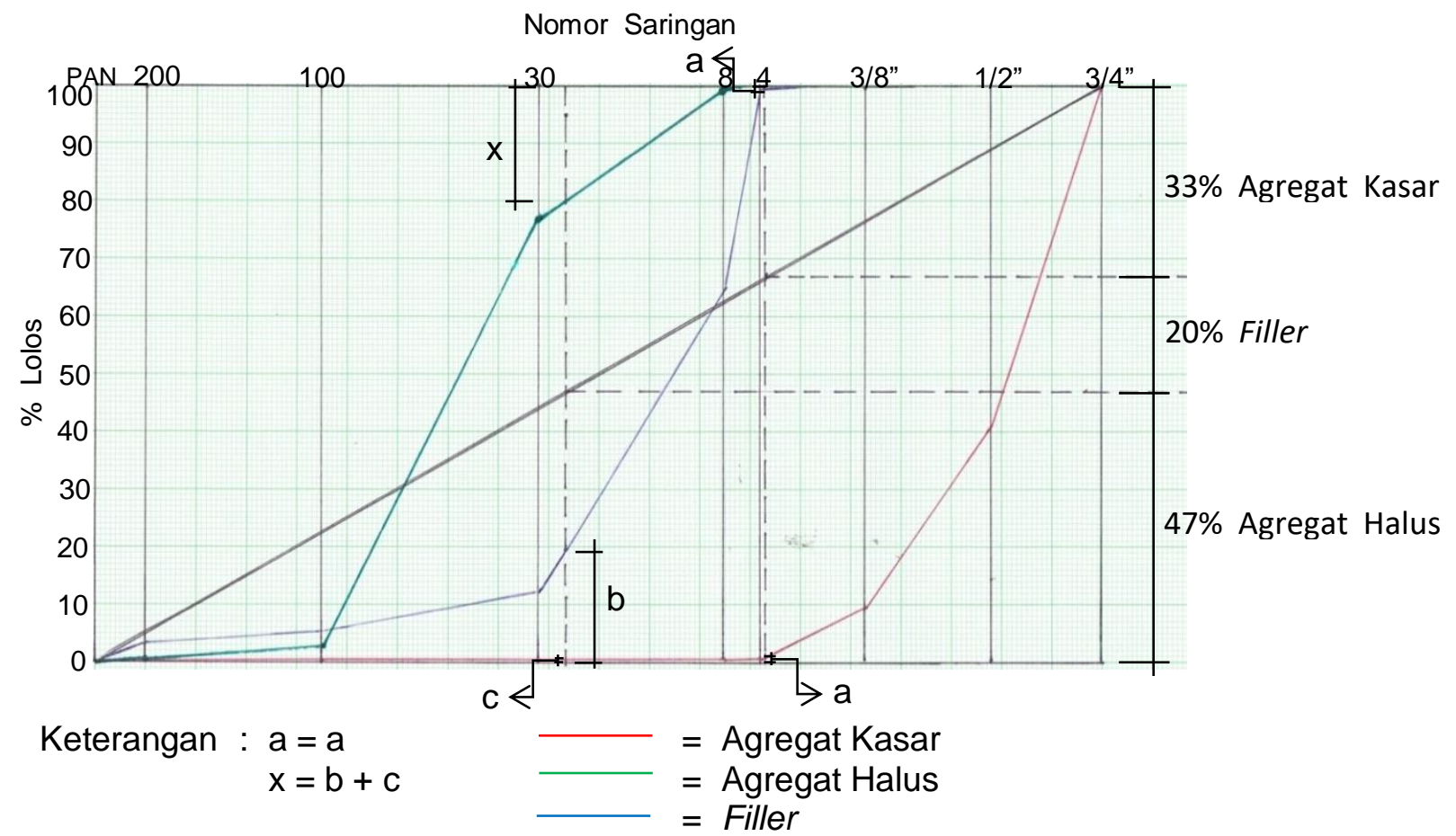

Gambar 3. Grafik Diagonal Penggabungan Agregat

Penetapan persentase agregat gabungan seperti pada gambar 3 di atas, telah memenuhi batas gradasi yang disyaratkan untuk lapis perkerasan HRS A, seperti terlihat pada grafik kurva gradasi agregat berikut ini

Grafik Lengkung Gradasi

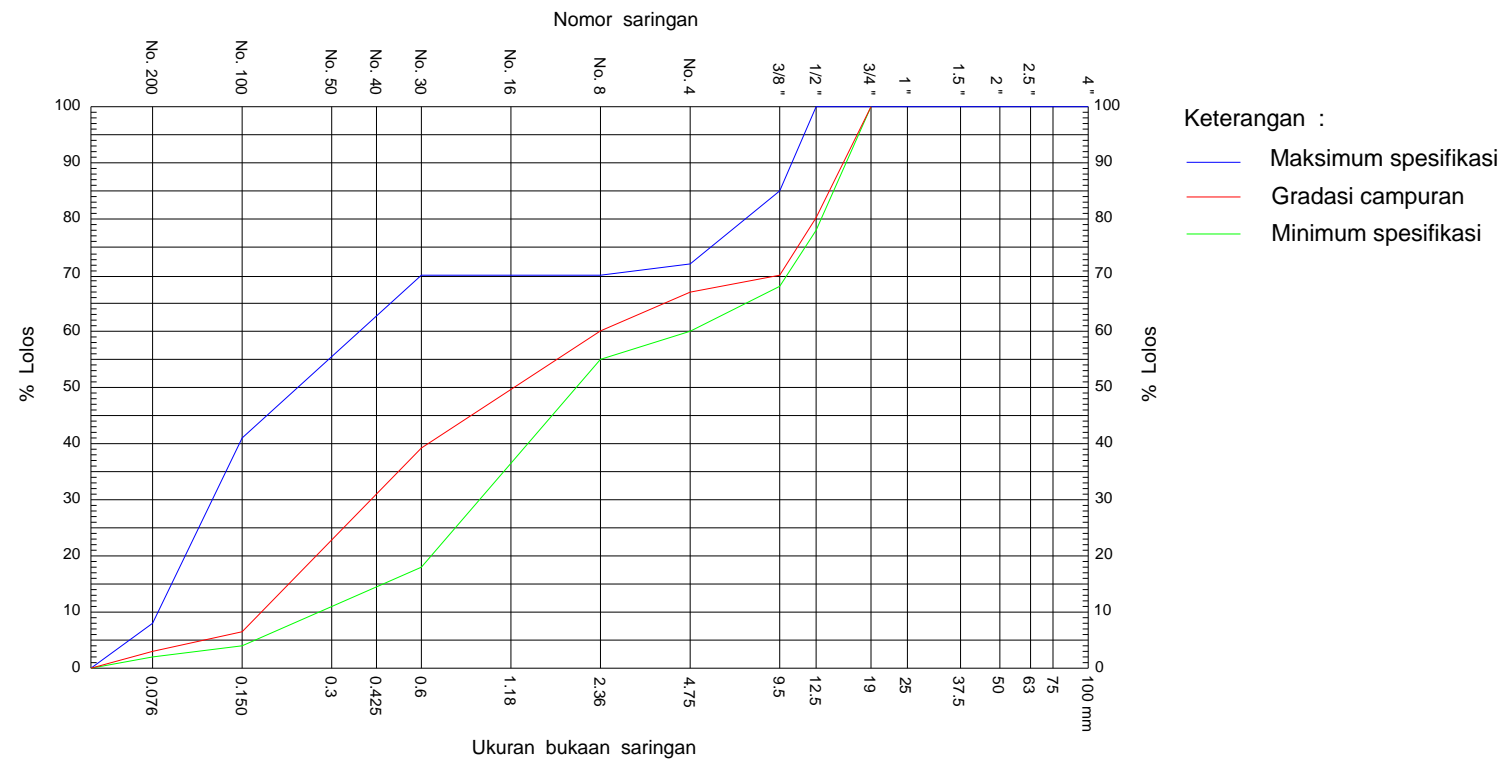

Gambar 4. Grafik Lengkung Gradasi

\section{Penentuan Perkiraan Kadar Aspal Rencana}

Setelah didapatkan hasil persentase dari masing - masing agregat yang digunakan baik agregat kasar, agregat halus maupun filler, seperti yang terlihat pada gambar 4.1. maka agregat kasar menempati porsi 33,00\%, agregat halus 47,00\% dan filler $20,00 \%$. Nilai konstanta untuk LATASTON jenis HRS A adalah 2 - 3. Jika konstanta diambil 
sebesar 2 maka kadar aspal rencana $(\mathrm{Pb})$ didapatkan $=9,00 \%$. Berdasarkan $\mathrm{Pb}$ yang diperoleh, maka perkiraan rentang kadar aspal rencana 8,0 8,5 9.0 9,5 10. Untuk selanjutnya dengan berdasarkan nilai kadar aspal tersebut, dilakukan perhitungan proporsi berat untuk masing - masing agregat, filler, dan aspal yang digunakan dalam campuran.

\section{Hasil Uji Marshall untuk Penentuan Kadar Aspal Optimum (KAO)}

Hasil pengujian Marshall tidak lain adalah pengujian sifat campuran beraspal dan dapat diperoleh setelah seluruh persyaratan material, berat jenis dan perkiraan kadar aspal rencana terpenuhi. Hasil uji Marshall untuk penentuan Kadar Aspal Optimum (KAO) untuk campuran HRS A

Tabel 2. Penentuan Kadar Aspal Optimum (KAO)

\begin{tabular}{|c|c|c|c|c|c|}
\hline \multirow{2}{*}{ REGAP OF MARSHALL TEST } & \multicolumn{5}{|c|}{ BINDER CONTENT (\%) } \\
\cline { 2 - 7 } & 8,0 & 8,5 & 9,0 & 9,5 & 10,0 \\
\hline VMA (\%) & & & & & \\
STABIITY (Kg) & & & & & \\
\hline & & & & & \\
\hline FLOW (mm) & & & & & \\
VOID IN MIX (VM) (\%) & & & & & \\
MARSHALL QUOTIENT (Kn/mm) & & & & & \\
\cline { 2 - 7 } & & & & & \\
\hline
\end{tabular}

Pada table 2 terlihat bahwa kadar aspal yang memenuhi kelima sifat campuran adalah pada rentang kadar aspal 9,50 \%. Setelah ditentukan Kadar Aspal Optimum (KAO) dari campuran perkerasan HRS A, maka penelitian dilanjutkan dengan pembuatan briket benda uji untuk uji perendaman menggunakan air laut dengan waktu rendaman yang bervariasi.

\section{Pengujian Keawetan Campuran terhadap Rendaman Air Laut}

Dalam pengujian keawetan campuran terhadap rendaman air laut digunakan benda uji yang telah memenuhi syarat spesifikasi HRS A dan telah ditentukan Kadar Aspal Optimumnya. Kadar Aspal yang memenuhi spesifikasi yang ditetapkan adalah sebesar 9,50\%. Benda uji ini dibuat sebanyak 3 buah untuk masing - masing variasi waktu perendaman, dengan demikian akan dibutuhkan benda uji adalah waktu perendaman 4 jam 3 buah, waktu perendaman 8 jam 3 buah, waktu perendaman 12 jam 3 buah, waktu perendaman 16 jam 3 buah, waktu perendaman 20 jam 3 buah, waktu perendaman 24 jam 3 buah, sehingga jumlah total benda uji 24 buah

Dalam pembuatan briket benda uji digunakan jumlah tumbukan standar Marshall yaitu 2 x 75 tumbukan. Jumlah tumbukan ini akan mempengaruhi sifat - sifat campuran Marshall seperti VMA, Stabilitas, Flow, VIM dan Marshall Quotient. Semakin padat sebuah campuran maka rongga udara akan semakin berkurang sehingga nilai stabilitas meningkat.

Pengujian ini prinsipnya sama dengan pengujian Marshall standar, hanya air rendaman dan waktu perendaman saja yang divariasikan. 


\section{Hasil Analisis Marshall dengan Kadar Aspal Optimum untuk Variasi Waktu Rendaman menggunakan Air Laut}

Setelah melakukan perendaman yang bervariasi waktunya terhadap benda uji tipe perkerasan HRS A dengan Kadar Aspal Optimum 9,50\%, maka selanjutnya dilakukan uji Marshall untuk mengetahui sifat - sifat campuran yang terjadi apabila ada perlakuan benda uji dengan media rendaman menggunakan air laut dan variasi waktu rendaman yang berbeda - beda. Hasil uji Marshall pada masing - masing variasi waktu rendaman dapat dilihat pada tabel 4.17. berikut ini :

Tabel 3. Pengaruh Lama Perendaman menggunakan Air Laut terhadap Karakteristik Marshall dan Perendaman Modifikasi pada Kondisi standard ( 2x75 tumbukan)

\begin{tabular}{|c|c|c|c|c|c|c|c|}
\hline \multirow{2}{*}{$\begin{array}{l}\text { Karakteristik } \\
\text { Marshall }\end{array}$} & \multicolumn{6}{|c|}{ Variasi Waktu Rendaman } & \multirow{2}{*}{ Spek. } \\
\hline & 4 Jam & 8 Jam & $\begin{array}{c}12 \\
\text { Jam }\end{array}$ & 16 Jam & $\begin{array}{c}20 \\
\text { Jam }\end{array}$ & 24 Jam & \\
\hline $\begin{array}{l}\text { Void Mineral in } \\
\text { Aggregatte (VMA) } \\
(\%)\end{array}$ & 23,52 & 24,71 & 25,83 & 26,00 & 26,23 & 25,20 & Min.18 \\
\hline Stability $(\mathrm{Kg})$ & $\begin{array}{c}450,6 \\
5\end{array}$ & $\begin{array}{c}340,2 \\
0\end{array}$ & $\begin{array}{c}304,3 \\
9\end{array}$ & 304,10 & $\begin{array}{c}216,1 \\
7\end{array}$ & 148,12 & $\begin{array}{c}450- \\
850\end{array}$ \\
\hline Flow (mm) & 2,07 & 2,17 & 2,80 & 2,93 & 5,23 & 7,17 & $2-4$ \\
\hline $\begin{array}{l}\text { Void In Mix (VIM) } \\
(\%)\end{array}$ & 5,92 & 7,39 & 8,77 & 8,97 & 9,25 & 7,99 & $4-6$ \\
\hline $\begin{array}{l}\text { Marshall Quotient } \\
(\mathrm{KN} / \mathrm{mm})\end{array}$ & 2,13 & 1,74 & 1,08 & 1,03 & 0,40 & 0,20 & $1-4$ \\
\hline
\end{tabular}

Variasi waktu perendaman serta media rendaman air laut akan berpengaruh terhadap sifat - sifat campuran beraspal sebagaimana dalam penjelasan berikut :

a) Hubungan antara variasi waktu rendaman dengan Void Mineral in Aggregatte (VMA)

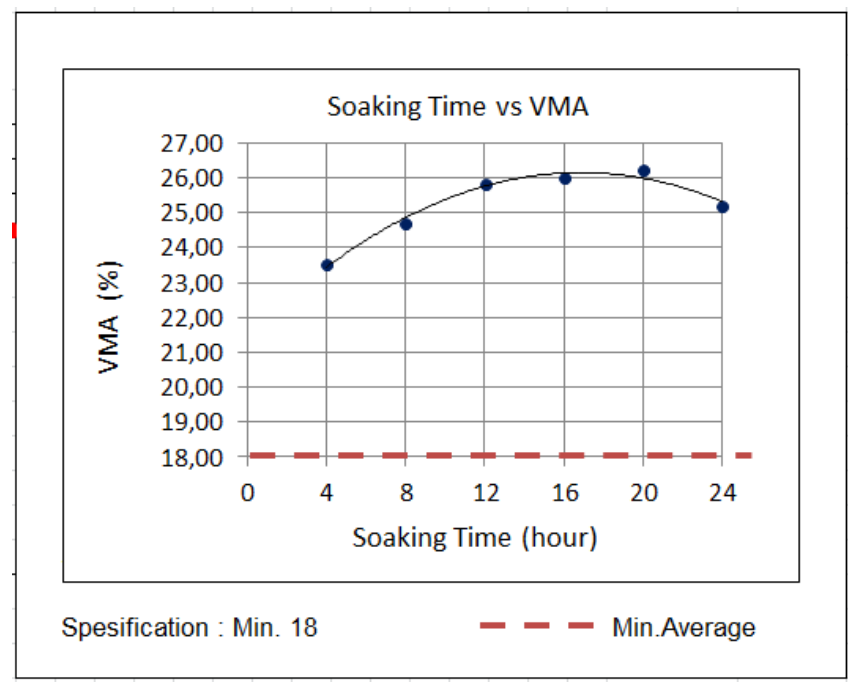

Gambar 5. Hubungan antara Waktu Rendaman dengan VMA 
b) Hubungan antara variasi waktu rendaman dengan Stabilitas

Hubungan antara sifat stabilitas dengan variasi waktu rendaman menggunakan air laut ini, disajikan dalam bentuk grafik pada gambar 6 sebagai berikut :

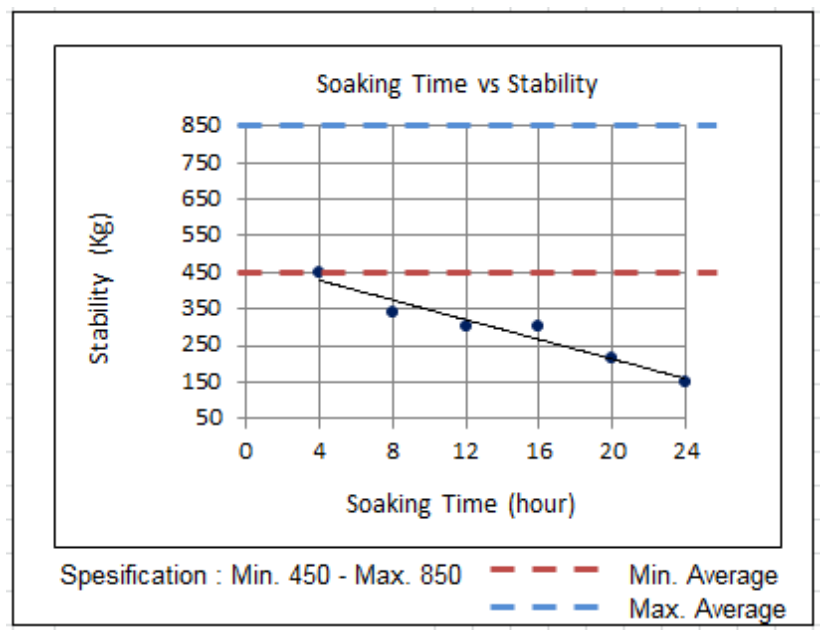

Gambar 6. Hubungan antara Waktu Rendaman dengan Stabilitas

c) Hubungan antara variasi waktu rendaman Flow

Hubungan antara sifat Flow dengan variasi waktu rendaman menggunakan air laut ini, disajikan dalam bentuk grafik pada gambar 7 sebagai berikut:

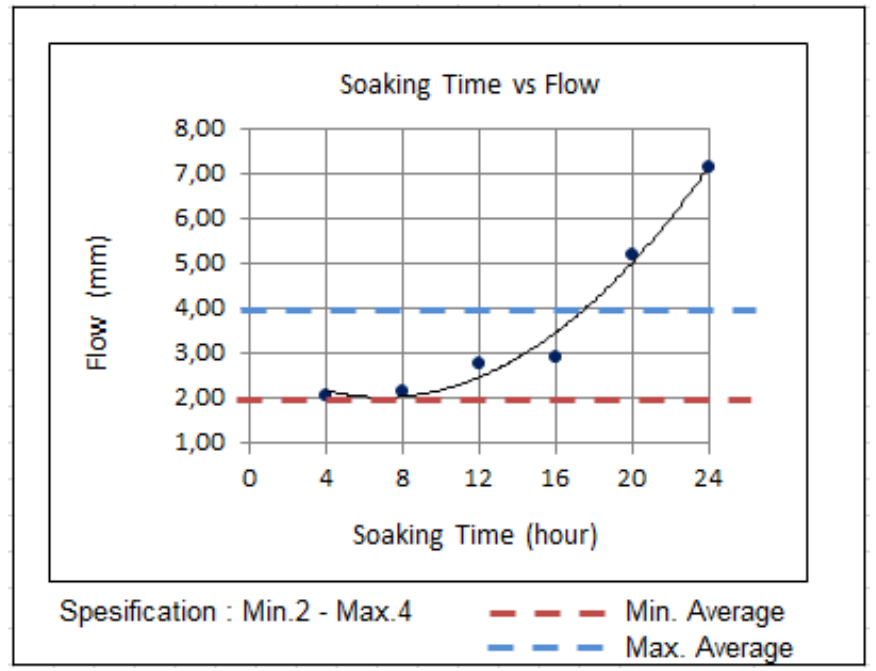

Gambar 7. Hubungan antara Waktu Rendaman dengan Flow

d) Hubungan antara variasi waktu rendaman dengan Void In Mix (VIM)

Hubungan antara sifat VIM dengan variasi waktu rendaman menggunakan air laut ini, dapat dilihat pada gambar 8 . sebagai berikut : 


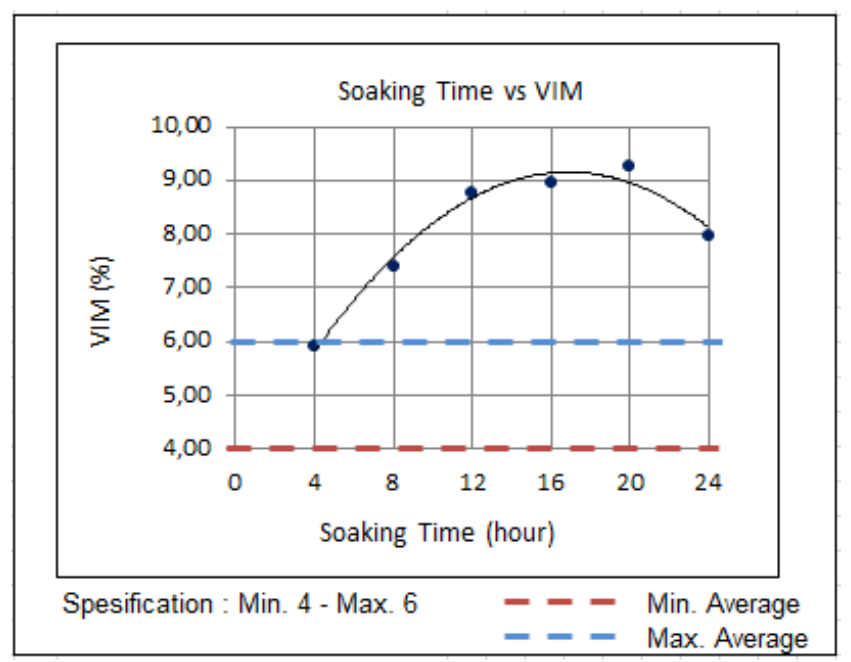

Gambar 8. Hubungan antara Waktu Rendaman dengan VIM

e) Hubungan antara variasi waktu rendaman dengan Marshall Quotient

Hubungan antara sifat Marshall Quotient dengan variasi waktu rendaman menggunakan air laut ini, dapat dilihat dalam bentuk grafik pada gambar 4.8. sebagai berikut :

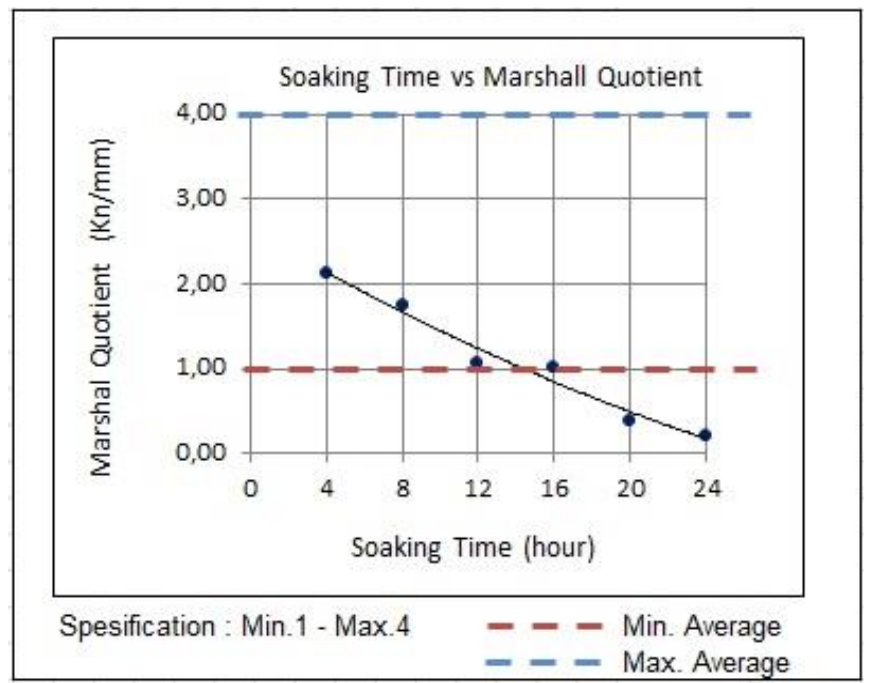

Gambar 9. Hubungan antara Waktu Rendaman dengan Marshall Quotient

\section{Analisis Indeks Stabilitas Sisa (IRS) Akibat Pengaruh Variasi Rendaman Menggunakan Air Laut}

Indeks Stabilitas Sisa (IRS) merupakan persentase minimum terhadap nilai Stabilitas Marshall. Nilai sifat keawetan dari campuran dapat ditunjukkan dengan nilai indeks stabilitas sisa yang berasal dari penurunan nilai stabilitas akibat pengaruh variasi rendaman menggunakan air laut.

Dari hasil pengujian variasi rendaman menggunakan air laut pada mutu perkerasan HRS-A diperoleh nilai - nilai stabilitas yang tertera dihasilkan. Dari hasil nilai stabilitas pada masing - masing variasi waktu rendaman seperti yang didapatkan maka dapat dihitung persentase Indeks Stabilitas Sisa akibat pengaruh variasi waktu rendaman air laut yang dimulai dari rentang waktu 4 Jam kemudian dilanjutkan pada rentang waktu 8 jam, 12 Jam, 16 Jam, 20 Jam dan 24 Jam. Hasil selengkapnya dapat dilihat dalam tabel 4 di bawah : 
Tabel 4. Nilai Indeks Stabilitas Sisa Mutu Perkerasan HRS-A akibat Pengaruh Variasi Waktu Rendaman Air Laut

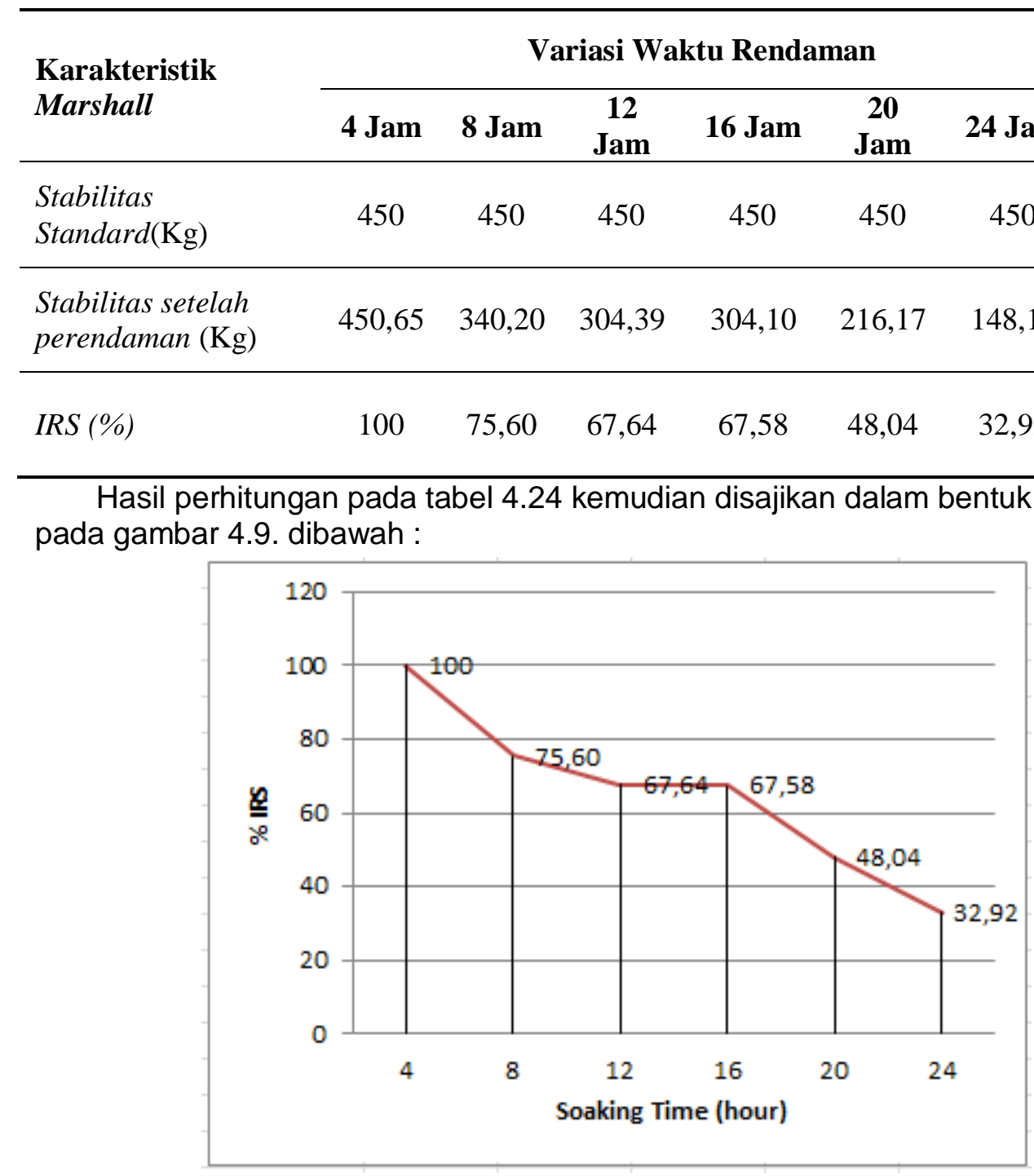

Gambar 10. Indeks Stabilitas Sisa (IRS) akibat Variasi Rendaman Air Laut

\section{KESIMPULAN}

Berdasarkan pembahasan dan uraian - uraian penelitian ini, maka dapat ditarik kesimpula, sebagai berikut :

a) Berdasarkan hasil pengujian dan analisa data karakteristik Marshall yang diakibatkan oleh pengaruh rendaman air laut terhadap mutu perkerasan HRS A, diperoleh hasil bahwa mutu perkerasan HRS A hanya dapat bertahan selama 4 jam akibat rendaman air laut. Hal ini menunjukkan bahwa rendaman atau genangan air laut dapat merusak keawetan mutu perkerasan.

b) Setelah melakukan uji perendaman menggunakan air laut diperoleh Indeks Stabilitas Sisa (IRS) pada rentang waktu perendaman 24 jam yaitu sebesar 32,92\%. Hal ini diakibatkan oleh pengaruh air laut yang merusak lapisan aspal yang menyelimuti perkerasan sehingga perekatan antar agregat semakin berkurang. Ini 
ditunjukkan oleh nilai VIM (Void in Mix) untuk rentang waktu 24 jam mencapai $7,99 \%$.

\section{DAFTAR PUSTAKA}

AASHTO. (1993). Guide For Design Of Pavement Structure. Washington DC.

Agung Hari Prabowo. (2003). Jurnal Pilar Volume 12, Nomor 2. Semarang.

ASTM. (1980). Annual Book Of ASTM Standart, Parts Road Paving.

Anonimus. (2006). Direktorat Jendral Bina Marga. Jakarta : Departemen Pekerjaan Umum.

Anonimus. (1976). Manual Pemeriksaan Bahan Jalan NO. 01/MN/BM/1976. Direktorat Jenderal Bina Marga, Departemen Pekerjaan Umum.

Anonimus. (1999). Pedoman Perencanaan Campuran Beraspal Panas dengan Pendekatan Kepadatan Mutlak. Teknik No. 025/T/BM/1999 Departemen Pekerjaan Umum. Jakarta : PT. Medisa.

Anonimus. (2001). Proyek Peningkatan Jalan Direktorat Jenderal Prasarana Wilayah. Departemen Pekerjaan Umum.

Anonimus. (2001). Spesifikasi Umum, Buku 5. Jakarta : Departemen Pekerjaan Umum.

Boyd, C. E. (1982). Water in Warn Water Fish Pond Agricultural Experiment Station. Alabama University.

Boyd, C. E. (1990). Water Quality in Ponds for Aquaculture Alabama Agricultural Experiment Station. Alabama University.

Craus, J. Et al. (1981). Durability Of Bituminous Paving Mixtures Of Related to Filler Type and Properties proceedings Association of Asphalt Paving Technologies Technical Sessions. San Diego : Volume SO

Effendi, H. (2003). Telaah Kualitas Air. Yogyakarta : Kanisius.

Hutagalung, H.P, D dan S. H. Riyono. (1997). Metode Analisis Air Laut, Sedimen dan Biota. Jakarta : LIPI.

Romi Moharto, K. Juwana, S. (2001). Biologi Laut Ilmu Pengetahuan Tentang Biota Laut. Jakarta : Djambatan.

Sutrisno, T. (2004). Teknologi Penyediaan Air Bersih. Jakarta : PT. Bineka Cipta.

Sukirman Silvia, Ir. (1995). Perkerasan Lentur Jalan Raya. Bandung : Nova.

Sukirman Silvia, Ir. (2003). Beton Aspal Campuran Panas. Jakarta : Granit.

Wignall, Arthur. (2003). Proyek Jalan. Jakarta : Erlangga. 